die beiden hexagonalen Proben meßbare kubische Strukturanteile besitzen, wo das $\mathrm{ZnS} /\left(5 \cdot 10^{-4}\right) \mathrm{Cu} /$ $150{ }^{\circ} \mathrm{C}$ einen etwas größeren kubischen Anteil aufweist als $\mathrm{ZnS} /\left(5 \cdot 10^{-4}\right) \mathrm{Cu} / 350^{\circ} \mathrm{C}$. Durch das Tempern wird in den mit $\left(5 \cdot 10^{-4}\right) \mathrm{Cu}$-dotierten $\mathrm{ZnS}$ Leuchtstoffen das Verhältnis von kubischen zu hexagonalen Strukturanteilen etwas verändert. So zeigen auch Gobrecht et al. ${ }^{4}$, daß die Aktivatorkonzentration einen wesentlichen Einfluß auf die Kristallstruktur der dotierten Zinksulfide hat.

Spektrale Untersuchungen der Thermolumineszenz der $\mathrm{ZnS} /\left(5 \cdot 10^{-4}\right) \mathrm{Cu}$-Leuchtstoffe ergeben, daß das Glowlicht beider Proben aus blauer und grüner

1 N. Riehl u. H. Ortmann, Monographie, Verlag Chemie, Weinheim 1957.

2 D. Curie, „Luminescence in Crystals", Methuen, London 1963.
Emission zusammengesetzt ist. $\mathrm{ZnS} /\left(5 \cdot 10^{-4}\right) \mathrm{Cu} /$ $150{ }^{\circ} \mathrm{C}$ emittiert im wesentlichen blaues Thermolumineszenzlicht. Für das Verhältnis der Intensitäten der blauen Spontanlumineszenz des $\mathrm{ZnS} /\left(5 \cdot 10^{-4}\right)$ $\mathrm{Cu} / 150{ }^{\circ} \mathrm{C}$ bei der Temperatur des flüssigen Stickstoffs (TfS) und Raumtemperatur (RT) finden wir bei $320 \mathrm{~nm}$-Anregung $I_{\mathrm{TPS}} / I_{\mathrm{RT}}=1,1$, bei $360 \mathrm{~nm}$ Anregung 1,2. Daraus folgt, daß auch bei den $\mathrm{ZnS} /\left(5 \cdot 10^{-4}\right) \mathrm{Cu}$-Leuchtstoffen eine Temperaturlöschung der Lumineszenz die Abnahme der Höhe der Hochtemperatur-Glowmaxima nicht erklären kann.

${ }^{3}$ L. Mader u. N. Riehl, Z. Phys. 206, 319 [1967].

${ }^{4}$ H. Gobrecht, H. Nelkowski u. P. Albrecht, Z. Naturforsch. 16 a, 857 [1961].

\section{Interdiffusion of Silver Ions in Molten Thallous Nitrate}

Anders Behn and Carl-Axel Sjöblom

Department of Physics, Chalmers University of Technology, Gothenburg, Sweden.

(Z. Naturforsch. 28 a, 1379-1380 [1973] ; received 20 June 1973)

The interdiffusion coefficient of silver ions in molten thallous nitrate has been determined with the gravimetric technique. The observed data can be "least-squares" fitted into an Arrhenius equation

$$
D_{12}=1.07 \times 10^{-3} \exp -(4130 \pm 400) / R T
$$

where $D_{12}$ is expressed in $\mathrm{cm}^{2} \mathrm{~s}^{-1}, R$ in calories equivalent ${ }^{-1}$, and $T$ in degrees K. Friction coefficients $r_{\mathrm{AgTl}}$ calculated according to the Klemm ${ }^{1}$ model indicate association between the cations, as has been indicated in mixtures of silver nitrate with heavy alkali nitrates also.

The interdiffusion coefficients of silver ions in mixtures of silver nitrate with other nitrates have been measured with different techniques and by different workers as reviewed most recently by Mazzocchin and Schiavon ${ }^{2}$. The agreement between the different sets of data is generally very good, although some differences still seem to exist between the results of different methods: The chronopotentiometric results by Bowcott and Plunkett ${ }^{3}$ deviate from the rest. This difference might be systematic in nature, as argued by Angell and Tomlinson ${ }^{4}$, who have observed considerable discrepancies in measurements with the chronopotentiometric method in solutions of cadmium in molten cadmium chloride. The results

Reprint requests to Dr. C.-A. Sjöblom, Department of Physics, Chalmers University of Technology, Gothenburg, Sweden. by Mazzocchin and Schiavon ${ }^{2}$ on the other hand, which are also obtained chronopotentiometrically, agree very well with data from "conventional" methods (i.e. tracer, optical, and gravimetric methods). Since no independent interdiffusion coefficients for silver ions in thallous nitrate are available it was decided to measure them with the gravimetric technique ${ }^{5,6}$.

\section{Experimental}

Commercially available reagent grade salts were used after drying at $150{ }^{\circ} \mathrm{C}$ for 50 hours. $\mathrm{AgNO}_{3}$ was obtained from Riedel de Haen AG, Hannover, $\mathrm{BRD}$, and $\mathrm{TlNO}_{3}$ from E. Merck AG, Darmstadt, BRD.

The general features of the experimental procedure are described elsewhere ${ }^{6}$. Commercial fritted quartz glass discs (diameter $20 \mathrm{~mm}$, thickness 3.5 $\mathrm{mm})$ were used. The disc was filled with an $\mathrm{AgNO}_{3}-\mathrm{TINO}_{3}$ mixture containing 10 mole\% $\mathrm{AgNO}_{3}$ which was allowed to diffuse out into a pure $\mathrm{TINO}_{3}$ melt. The diffusion coefficient determined in this way is the interdiffusion coefficient of $\mathrm{Ag}^{+}$-ions in $\mathrm{TlNO}_{3}{ }^{6}$. No additional salt flow due to the density difference between the melts inside and outside the disc was detected. The buoyancy of the disc during the diffusion was determined with an electrical balance, Mettler H20E GD, which was connected to a 2-channel potentiometric recorder, Goerz Servogor 2. The temperature of the melts was measured with a Platinel ${ }^{7}$ thermocouple connected to a Zeref temperature reference chamber and the second channel on the recorder. The experiments were performed in an electrical furnace to which a 
constant heating current was fed from a voltage stabilizer and a variable transformer. The room temperature was thermostated. In this way the melt temperature could be kept constant to better than $1^{\circ} \mathrm{K}$ (the reading accuracy of the recorder). Linear regression performed on a Canola $164 \mathrm{P}$ calculator was used in order to calculate the slope of the logarithm of the apparent weight of the cell versus time. An improvement in accuracy and speed in determining the interdiffusion coefficients was obtained in this way.

\section{Results and Discussion}

The observed interdiffusion coefficients of silver ions in molten thallous nitrate are plotted in Figure 1. The data can be "least squares" fitted to an Arrhe-

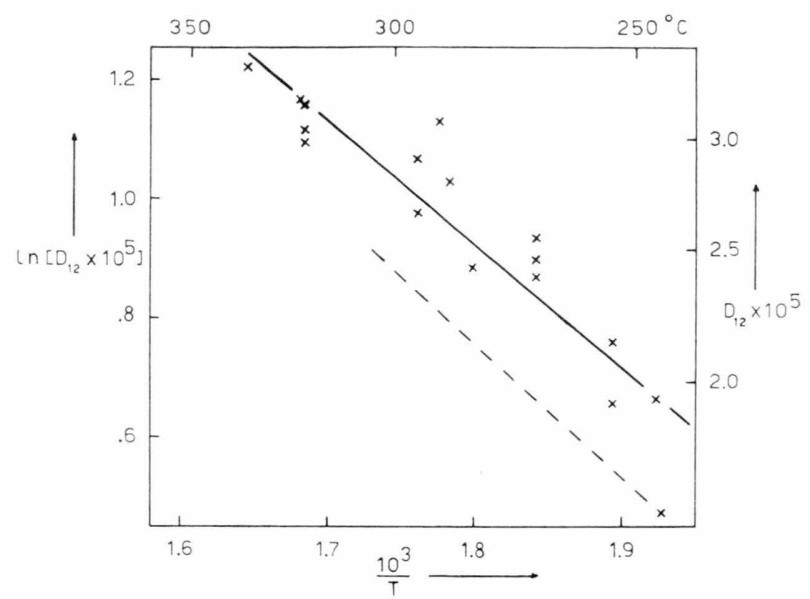

Fig. 1. The interdiffusion coefficient $D_{12}$ of silver ions in molten thallous nitrate. Arrhenius line according to the present work - according to Mazzocchin and Schiavon ${ }^{2}---$. (The value $D=3.05 \mathrm{~cm}^{2} / \mathrm{s}$ at $321^{\circ} \mathrm{C}$ in the present work was obtained twice.)

1 A. Klemm, Z. Naturforsch. 15 a, 173 [1960].

2 G.-A. Mazzocchin and G. Schiavon, J. Eelectroanal. Chem. 38, 229 [1972].

3 J. E. L. Bowcott and B. A. Plunkett, Electrochim. Acta 14, 363 [1969].

4 C. A. Angell and J. W. Tomlinson, Electrochemistry, Proc. 1st Austral. Conf., Pergamon Press, London 1964, p. 557.

5 C.-A. Sjöblom, Z. Naturforsch. 20 a, 1572 [1965].

${ }^{6}$ D. Andréasson, A. Behn, and C.-A. Sjöblom, ibid. 25 a, 700 [1970]. nius equation in the temperature interval $519-608$ ${ }^{\circ} \mathrm{K}$ :

$$
D_{12}=1.07 \times 10^{-3} \exp -(4130 \pm 400) / R T
$$

(the stated error is a standard deviation) where $D$ is expressed in $\mathrm{cm}^{2} \mathrm{~s}^{-1}, R$ in cal equiv ${ }^{-1}$, and $T$ in degrees $\mathrm{K}$. The standard error of estimate ${ }^{8}$ of this equation is about $6 \%$. The corresponding equation by Mazzocchin and Schiavon ${ }^{2}$ is

$$
D_{12}=1.22 \times 10^{-3} \exp (-4470 / R T)
$$

which is calculated for the temperature interval $490-578{ }^{\circ} \mathrm{K}$ [Equations (1) and (2) are plotted in Figure 1]. The temperature ranges do not coincide exactly, but the agreement between the preexponential factors and between the activation energies in the two equations is still very good (the difference between the observed data is on the average less than $7 \%$ ). It may thus be concluded that no systematic differences between the chronopotentiometric technique and the present technique can be observed in the case of silver ion interdiffusion in molten thallous nitrate.

Previous work on silver ion interdiffusion in nitrates of heavy alkali metals ( $\mathrm{Rb}$ and $\mathrm{Cs}$ ) give evidence of association between the two different kinds of cations ${ }^{6}$. The same kind of argument, based on the friction-coefficient formalism by Klemm ${ }^{1}$ may be applied here ${ }^{9}$. It is found that the friction coefficient $r_{\mathrm{AgTl}}=-3.2 \times 10^{8}$ joule s cm $\mathrm{cm}^{-2} \mathrm{~mole}^{-1}$ at $250{ }^{\circ} \mathrm{C}$ and $-2.2 \times 10^{8}$ at $300^{\circ} \mathrm{C}$. As expected, the degree of association decreases when the temperature increases.

\section{Acknowledgement}

This work was financially supported by "C. F. Lundströms Stiftelse" which is gratefully acknowledged.

7 Obtained from Engelhard Industries AB, Stockholm, Sweden.

8 A. G. Worthing and J. Geffner, Treatment of Experimental Data, John Wiley \& Sons, Inc., N. Y., 3rd, ed. 1964, p. 273.

9 In order to calculate the cation-cation friction coefficient $r$ AgTl one has to assume that the cation-anion coefficients $r_{\mathrm{AgNO}}$ and $\mathrm{rTlNO}_{3}$ are equal to each other. This is a quite reasonable assumption, as pointed out by C.-A. Sjöblom and A. Behn, Z. Naturforsch. 23 a, 1774 [1968]. 